\title{
COLOR, PIGMENT AND RESIDUAL NITRITE OF DENDENG SAPI NATURALLY CURED AT VARIOUS LEVEL OF CELERY LEAVES AND INCUBATION TEMPERATURES
}

\author{
E. Saputro ${ }^{1,2}$, V. P. Bintoro ${ }^{1}$ and Y. B. Pramono ${ }^{1}$ \\ ${ }^{I}$ Faculty of Animal and Agricultural Sciences, Diponegoro University, \\ Tembalang Campus, Semarang 50274 - Indonesia \\ ${ }_{2}^{2}$ Permanent Address: National Animal Husbandry Training Center, \\ Jl. Songgoriti No. 24, Batu 65301 - Indonesia \\ Corresponding E-mail: vepebe@yahoo.com
}

Received February 10, 2016; Accepted March 29, 2016

\begin{abstract}
ABSTRAK
Penelitian ini bertujuan untuk menganalisis pengaruh kyuring alami menggunakan berbagai level daun seledri segar (DSS) dan berbagai level suhu inkubasi. Suhu inkubasi dibedakan menjadi suhu ruang (SR) dan suhu $40,6^{\circ} \mathrm{C}(40,6)$ selama 2 jam pada pembuatan dendeng sapi yang dapat memberikan karakteristik kyuring yang mirip dengan kontrol yang ditambahkan 50 ppm natrium nitrit $\left(\mathrm{NaNO}_{2}\right)$. Empat perlakuan dendeng sapi kyuring alami adalah $\mathrm{A}_{1}=22 \mathrm{~g}$ DSS $/ \mathrm{kg}$ daging sapi, SR; $\mathrm{A}_{2}=36 \mathrm{~g}$ $\mathrm{DSS} / \mathrm{kg}$ daging sapi, SR; $\mathrm{A}_{3}=22 \mathrm{~g}$ DSS $/ \mathrm{kg}$ daging sapi, 40,6; $\mathrm{A}_{4}=36 \mathrm{~g} \mathrm{DSS} / \mathrm{kg}$ daging sapi, 40,6 dan 1 perlakuan dendeng sapi kyuring konvensional dengan penambahan $50 \mathrm{ppm} \mathrm{NaNO} \mathrm{N}_{2}$ sebagai kontrol $\left(\mathrm{A}_{0}\right)$. Semua dendeng sapi kyuring alami $\left(\mathrm{A}_{1}-\mathrm{A}_{4}\right)$ menunjukkan warna, pigmen kyuring, total pigmen dan residu nitrit yang tidak berbeda nyata $(\mathrm{P}>0,05)$ dengan dendeng sapi kyuring konvensional yang ditambahkan $50 \mathrm{ppm} \mathrm{NaNO}_{2}\left(\mathrm{~A}_{0}\right)$. Daun seledri segar yang digunakan dalam penelitian ini merupakan pengganti efektif untuk $\mathrm{NaNO}_{2}$ pada level yang diuji untuk memproduksi dendeng sapi kyuring alami. Hasil penelitian ini mengindikasikan level DSS yang lebih rendah $(22 \mathrm{~g} / \mathrm{kg}$ daging sapi) dan cara inkubasi selama 2 jam di suhu ruang lebih efektif menghasilkan dendeng sapi kyuring alami yang sebanding dengan dendeng sapi kyuring konvensional yang ditambahkan $50 \mathrm{ppm} \mathrm{NaNO}_{2}$.

Kata kunci: kyuring alami, daun seledri segar, dendeng sapi, pigmen kyuring, residu nitrit
\end{abstract}

\begin{abstract}
This study was conducted to analyze the effect of natural curing by various levels of fresh celery leaves (FCL) and various levels of incubation temperature. The incubation temperature was room temperature (RT) and temperature of $40.6^{\circ} \mathrm{C}$ (40.6) for 2 hours. These incubation temperatures for creating dendeng sapi were designed to provide the similar curing characteristics of the control (by addition of $50 \mathrm{ppm}$ of $\mathrm{NaNO}_{2}$ ). Four naturally cured dendeng sapi treatments were $\mathrm{A}_{1}=22 \mathrm{~g} \mathrm{FCL} / \mathrm{kg}$ of beef, RT; $\mathrm{A}_{2}=36 \mathrm{~g}$ FCL $/ \mathrm{kg}$ of beef, RT; $\mathrm{A}_{3}=22 \mathrm{~g} \mathrm{FCL} / \mathrm{kg}$ of beef, $40.6 ; \mathrm{A}_{4}=36 \mathrm{~g} \mathrm{FCL} / \mathrm{kg}$ of beef, 40.6 and a treatment of conventionally cured dendeng sapi by addition of $50 \mathrm{ppm} \mathrm{NaNO}_{2}$ as a control $\left(\mathrm{A}_{0}\right)$. All of the naturally cured dendeng sapi $\left(\mathrm{A}_{1}-\mathrm{A}_{4}\right)$ showed color, cured pigment, total pigment and residual nitrite which were not significantly different compared with $\mathrm{A}_{0}$. The FCL used in this study was an effective replacement for sodium nitrite at the test levels in manufacturing natural cured dendeng sapi. These results indicated that at fewer FCL levels ( $22 \mathrm{~g} / \mathrm{kg}$ of beef) and a more practical of the incubation for 2 hours at room temperature were more effective to create naturally cured dendeng sapi.

Keywords: natural curing, fresh celery leaves, dendeng sapi, cured pigment, residual nitrite
\end{abstract}




\section{INTRODUCTION}

Dendeng sapi is jerky beef like Indonesian preserved beef by chemically and physically preservation. Dendeng sapi is made by the addition of kitchen salt $(\mathrm{NaCl})$, saltpetre (sodium nitrate/nitrite), sugar and Indonesian typical spices as a seasoning on thin slices of beef or ground meat then dried under sunlight or using a drying oven. Dendeng sapi is categorized as conventional curing beef products because of saltpeter (sodium nitrate/nitrite) addition in the composition of raw material. It has been established that nitrite may cause methaemoglobinemia and cancer. For this reason, many researchers investigate the alternatives such as natural curing.

Sebranek and Bacus (2007) described the process of meat curing called natural curing. This process uses natural ingredients that contain relatively high levels of nitrate naturally combined with a starter culture of bacteria producing nitrate reductase, which in turn reducing nitrate to become nitrite. Some vegetables, such as celery, was established to have high level of natural nitrate (Keeton et al., 2012). Reduction of nitrate to nitrite by the starter culture is done through the incubation step at a temperature. This may meet the specific requirements of microorganism growth over a certain period before the cooking/thermal processing step. Previous studies recommended a minimum incubation of 2 hours to generate enough nitrite and then to develop the characteristics of cured meat (Sindelar et al., 2007a; Sindelar et al., 2007b).

Sindelar et al. (2007a), Sindelar et al. (2007b), Sindelar et al. (2010), Terns et al. (2011a) and Terns et al. (2011b) used the natural curing agents in the form of vegetables or fruit juice powdered and Staphylococcus carnosus producing nitrate reductase. In this study, the authors used only natural curing agent in the form of fresh celery leaves (FCL) that naturally contains high nitrate and enzyme of nitrate reductase without a nitrate-reducing bacteria addition. Nitrate reduction rely on nitrate reductase from the fresh celery leaf and the nitrate-reducing bacteria naturally found in fresh meat (Pinotti et al., 2001). This study aimed to investigate the effect of natural curing by various levels of FCL and incubation temperature on color, cured pigment, total pigment and residual nitrite of dendeng sapi. This method was designed to provide similar curing characteristics to the control (by addition of $50 \mathrm{ppm} \mathrm{NaNO}_{2}$ ) during conventional curing of dendeng sapi.

\section{MATERIALS AND METHODS}

\section{Materials and Experimental Design}

The materials used in the present study were ground of fresh beef (bottom round) from local bulls of local Ongole crossbred (OC) about 3 years-old from Penggaron abattoir of Semarang City, sugar, spices, fresh celery leaves (FCL) as a natural curing agent and $\mathrm{NaNO}_{2}$ as a conventional curing agent. The study used the experimental design of split-plot on the basis of a randomized complete block design consisting 3 replicate groups of each. The main plot was curing treatments (A) consisting 4 natural curing treatments by various levels of FCL and incubation temperature for 2 hours (room temperature $=\mathrm{RT}$ and temperature of $40.6^{\circ} \mathrm{C}=$ 40.6). The levels of FCL were $A_{1}=22 \mathrm{~g} \mathrm{FCL} / \mathrm{kg}$ of beef, RT; $\mathrm{A}_{2}=36 \mathrm{~g}$ FCL $/ \mathrm{kg}$ of beef, RT; $\mathrm{A}_{3}=$ $22 \mathrm{~g} \mathrm{FCL} / \mathrm{kg}$ of beef, $40.6 ; \mathrm{A}_{4}=36 \mathrm{~g} \mathrm{FCL} / \mathrm{kg}$ of beef, 40.6) and a treatment of conventional curing by $50 \mathrm{ppm}$ sodium nitrite-added as a control $\left(\mathrm{A}_{0}\right)$. The subplot was 3 periods of storage or $0,14^{\text {th }}$ and $28^{\text {th }}$ observation days with the sample of their own. The replicate groups were the origin of bottom round 1, 2 and 3 .

Bottom round was trimmed in order to clean of external fat and ground, then was randomly placed in a container (each $1 \mathrm{~kg}$ for each treatment). Dendeng sapi formulation based on Suryati et al. (2014) which consists of the following materials: $1 \mathrm{~kg}$ of ground fresh beef (bottom round), $16.5 \%$ brown sugar, white sugar $16.5 \%, 10 \%$ garlic, $8.5 \%$, galangal, $2.5 \%$ salt, $2.0 \%$ coriander, $0.3 \%$ white pepper, $0.3 \%$ tamarind, $0.3 \%$ lime and $0.3 \%$ ice/water (based on the weight of the fresh beef). Treatment of $\mathrm{A}_{0}$ was addition of $50 \mathrm{ppm} \mathrm{NaNO}_{2}$; treatments of $\mathrm{A}_{1}$ and $\mathrm{A}_{3}$ were added $22 \mathrm{~g}$ of $\mathrm{FCL}$; and treatment of $\mathrm{A}_{2}$ and $\mathrm{A}_{4}$ were added $36 \mathrm{~g}$ of FCL. The mixture of dendeng sapi $\mathrm{A}_{1}$ and $\mathrm{A}_{2}$ were incubated for 2 hours at room temperature. The mixture of dendeng sapi $\mathrm{A}_{3}$ and $\mathrm{A}_{4}$ were placed in an incubator and incubated for 2 hours at a temperature of $40.6^{\circ} \mathrm{C}$. The control $\left(\mathrm{A}_{0}\right)$ was dried directly in the oven after flaked by a thin 0.1 to $0.2 \mathrm{~cm}$ without incubation step. All treatments were dried using a drying oven for 2 hours at $63^{\circ} \mathrm{C}$ and reversed such that the bottom side was at the top, and then the drying was continued at 
$63^{\circ} \mathrm{C}$ for 2 hours to reach a water activity $\leq 0.85$. After drying, dendeng sapi pieces of each treatment for each sample of $0,14^{\text {th }}$ and $28^{\text {th }}$ day were placed in a plastic barrier bag polypropilene (PP) and packaged vacuum. They were stored at room temperature in a tightly closed container and opaque until analysis of color, pigment and residual nitritite.

Commission International d'Eclairage (CIE) $L^{*}$ (lightness), $a^{*}$ (redness) and $b^{*}$ (yellowness) were determined using a digital colorimeter for Macintosh. Measurements of surface color of dendeng sapi were taken after products were removed from vacuum packaging. Measurements were taken at 6 randomly selected areas on the sample and the average was used in data analysis. Mononitrosylhemochrome pigment (cured meat pigment) and total pigment concentrations were measured according to Hornsey (1956) after extraction in $80 \%$ acetone and acidified acetone, respectively. Residual nitrite was determined before incubation (preincubate), after incubation (postincubate) after drying (day 0) and continued throughout a 28-day of storage times. Residual nitrite were determined by the AOAC method (AOAC, 1990). All residual nitrite assays were done in duplicate and all treatments within a replication were analyzed at the same time to minimize the variation in the analysis due to time.

\section{Data Analysis}

Statistical analysis was performed for all measurement data using the SPSS procedures (version 17.0) using analysis of variance (ANOVA). The differences between treatments were tested further using the Tukey test. Significance level was determined at $5 \%$.

\section{RESULTS AND DISCUSSION}

\section{Color Measurement}

CIE $a^{*}$ (redness) values of non sodium nitrite dendeng sapi $\left(\mathrm{A}_{1}-\mathrm{A}_{4}\right)$ and sodium nitrite addition $\left(\mathrm{A}_{0}\right)$ indicated that the color was not red because all values were under zero. It is presumed that pink cured color produced by the curing reaction was covered by a brown color those resulted from the browning reaction. This was caused by heating temperature at $63^{\circ} \mathrm{C}$ for 4 hours on the brown sugar, and the addition of white sugar to the product which totals $33 \%$ of the weight.

No significant interactions were found between treatments and storage times for CIE $a^{*}$ values as shown in Table 1, but the main effect of storage times (time of observation) affected significantly $(\mathrm{P}<0.05)$ as shown in Table 2 . CIE $a^{*} \quad$ values significantly $(\mathrm{P}<0.05) \quad$ increased throughout storage times toward the red color values (zero). The nitrate concentration in fresh celery leaf as a reservoir for curing reactions may explain this occurrence. The average of nitrate concentration in celery is $1496 \mathrm{ppm}$, with the range from 20 to $4269 \mathrm{ppm}$, and the average of nitrite concentration in celery is $0.1 \mathrm{ppm}$ with the range from 0.02 to $0.5 \mathrm{ppm}$ (Keeton et al., 2012). Nitrite is highly reactive as a curing agent so that it will run out relatively quick from cured meat. Nitrate serves as an important reservoir in cured meat products to maintain an effective concentration of nitrite during heating/drying or storage in the long term (Sebranek, 2009).

A significant difference $(\mathrm{P}<0.05)$ was observed for the main effect of curing treatments as shown in Table 3. The $\mathrm{A}_{0}$ had the highest CIE $a^{*}$ values $(\mathrm{P}<0.05)$ compared with all other treatments. This was showed that the $\mathrm{A}_{0}$ had the largest number of reddish cured pigment.

Table 1 shows the mean of CIE $L^{*}$ (lightness) values of dendeng sapi in various storage times (days 0,14 and 28). There was no interactive effect between treatment and storage times for the CIE $L^{*}$ values of dendeng sapi. The CIE $L^{*}$ values were unchanged throughout storage times. This showed that the cured color was not fading throughout storage times. Although there was no significant difference, the $\mathrm{A}_{0}$ ər (the control) revealed a lighter color than all other treatments at day 0. Sindelar et al. (2010) reported that a lighter color suggests the existence of more darkish-colored metmyoglobin pigment and less reddish-colored nitrosylhemochrome pigment. When nitrite is added to ground beef, browning effect occurs because nitrite is so a strong oxidant to the heme in myoglobin, that thus myoglobin and oxymyoglobin are oxidised to metmyoglobin (Honikel, 2008). The reduction of nitrite into nitric acid may create an unstable intermediate pigment (nitrosyl-metmyoglobin) Because there are no endogenous and exogenous reductants adequately, nitrosylmetmyoglobin pigment may not autoreduct to form more stable dark red NO-myoglobin or nitrosylmyoglobin.

The mean of CIE $L^{*}$ values of $\mathrm{A}_{0}$ (the control) showed higher numerically at day 0 than at day 14 and 28 of storage times. This means that the nitrosylhemochrome pigment or fading cured color was decreasing throughout storage times. 
Table 1. The Means for Residual Nitrite, Cured Pigment, Total Pigment and CIE $L^{*}, a^{*}, b^{*}$ Values at Various Storage Times

\begin{tabular}{cccccccc}
\hline \multirow{2}{*}{ Treatments } & \multicolumn{3}{c}{ Storage times } & & \multicolumn{3}{c}{ Storage times } \\
\cline { 2 - 7 } \cline { 5 - 7 } & 0 & 14 & 28 & Treatments & 0 & 14 & 28 \\
\hline
\end{tabular}

(ppm)

Residual Nitrite

$\begin{array}{llll}\mathrm{A}_{\circ} & 0.060 & 0,084 & 0.050 \\ \mathrm{~A}_{1} & 0.048 & 0.073 & 0.054 \\ \mathrm{~A}_{2} & 0.053 & 0.089 & 0.035 \\ \mathrm{~A}_{3} & 0.038 & 0.083 & 0.045 \\ \mathrm{~A}_{4} & 0.061 & 0,072 & 0.083\end{array}$

SEM $^{\mathrm{a}} \quad 0.006$

CIE $L^{*}$ (Lightness) Values

$\begin{array}{llll}\mathrm{A}_{0} & 46.762 & 41.666 & 41.992 \\ \mathrm{~A}_{1} & 40.807 & 41.851 & 42.477 \\ \mathrm{~A}_{2} & 44.196 & 43.349 & 44.303 \\ \mathrm{~A}_{3} & 42.080 & 40.496 & 41.978 \\ \mathrm{~A}_{4} & 40.140 & 40.655 & 38.148 \\ & 0.542 & & \end{array}$

Cured Pigment (Nitrosylhemochrome)

CIE $a *$ (Redness) Values

$\begin{array}{cccccccc}\mathrm{A}_{\mathrm{o}} & 57.855 & 113.293 & 189.853 & \mathrm{~A}_{\mathrm{o}} & -3.177 & -2.505 & -2.603 \\ \mathrm{~A}_{1} & 37.072 & 141.230 & 139.683 & \mathrm{~A}_{1} & -5.093 & -5.605 & -4.197 \\ \mathrm{~A}_{2} & 99.470 & 155.150 & 186.180 & \mathrm{~A}_{2} & -6.066 & -5.139 & -4.971 \\ \mathrm{~A}_{3} & 41.180 & 146.933 & 211.217 & \mathrm{~A}_{3} & -5.912 & -4.540 & -4.207 \\ \mathrm{~A}_{4} & 35.090 & 88.063 & 185.987 & \mathrm{~A}_{4} & -5.931 & -5.504 & -4.929 \\ \mathrm{SEM}^{\mathrm{a}} & 13.353 & & & \text { SEM }^{\mathrm{a}} & 0.205 & & \end{array}$

Total Pigment

CIE $b^{*}$ (Yellowness) Values

$\begin{array}{cccccccc}\mathrm{A}_{\circ} & 444.040 & 260.893 & 244.120 & \mathrm{~A}_{\circ} & 18.297 & 15.613 & 16.496 \\ \mathrm{~A}_{1} & 577.433 & 248.653 & 424.547 & \mathrm{~A}_{1} & 16.642 & 12.110 & 13.988 \\ \mathrm{~A}_{2} & 340.567 & 384.427 & 493.227 & \mathrm{~A}_{2} & 17.187 & 13.552 & 16.140 \\ \mathrm{~A}_{3} & 371.280 & 264.293 & 338.867 & \mathrm{~A}_{3} & 18.528 & 13.276 & 16.121 \\ \mathrm{~A}_{4} & 247.633 & 259.080 & 471.240 & \mathrm{~A}_{4} & 18.035 & 14,500 & 14.514 \\ \text { SEM }^{\mathrm{a}} & 42.901 & & & \text { SEM }^{\mathrm{a}} & 0.527 & & \end{array}$

${ }^{a} \mathrm{SEM}=$ standard error of the means

The treatment of $\mathrm{A}_{0}$ was sodium nitrite addition merely, and no nitrate was added as a backup source of nitrite to regenerate the reaction for curing color development and stability throughout the storage times.

Table 1 shows the mean of CIE $b^{*}$ (yellowness) values of dendeng sapi from all treatments at various storage times (days 0,14 , 28). There were no interactive effect between treatment and storage times for CIE $b^{*}$ values, but
Table 2 shows that the main effect of storage times (time observation) was significantly different $(\mathrm{P}<0.05)$. At the day 14 of storage significantly $(\mathrm{P}<0.05)$ increased the CIE $b^{*}$ value, but at the day 0 of storage significantly $(\mathrm{P}<0.05)$ increased and at the day 28 of storage unchanged the CIE $b^{*}$ value. The CIE $b^{*}$ values were significantly decreased $(\mathrm{P}<0.05)$ or unchanged at the day 28 and day 0 of storages, respectively. 
Table 2. The Means for the Main Effect of Storage Times (Days 0, 14, 28) for CIE $a^{*}$ and $b^{*}$ Values and Cured Pigment

\begin{tabular}{lcccc}
\hline \multirow{2}{*}{\multicolumn{1}{c}{ Parameter }} & \multicolumn{3}{c}{ Storage times } & \multirow{2}{*}{ SEM } \\
\cline { 2 - 4 } & 0 & 14 & 28 & 0.205 \\
\hline CIE $a^{*}$ (redness) & $-5.236^{\mathrm{q}}$ & $-4.658^{\mathrm{pq}}$ & $-4.181^{\mathrm{p}}$ & 0.527 \\
CIE $b^{*}$ (yellowness) & $17.738^{\mathrm{p}}$ & $13.810^{\mathrm{q}}$ & $15.452^{\mathrm{pq}}$ & 13.353 \\
Cured Pigment (ppm) & $54.133^{\mathrm{q}}$ & $128.934^{\mathrm{pq}}$ & $182.584^{\mathrm{p}}$ & \\
\hline
\end{tabular}

p-q Means within same row with different superscripts are significant different $(\mathrm{P}<0.05)$. SEM : standard error of the means

Table 3. The Means for the Main Effect of Curing Treatment

\begin{tabular}{cc}
\hline Treatment & CIE $a *$ (redness) \\
\hline $\mathrm{A}_{\circ}$ & $-2.762^{\mathrm{p}}$ \\
$\mathrm{A}_{1}$ & $-4.965^{\mathrm{q}}$ \\
$\mathrm{A}_{2}$ & $-5.392^{\mathrm{q}}$ \\
$\mathrm{A}_{3}$ & $-4.886^{\mathrm{q}}$ \\
$\mathrm{A}_{4}$ & $-5.454^{\mathrm{q}}$ \\
$\mathrm{SEM}$ & 0.205 \\
\hline
\end{tabular}

SEM : standard error of the means

\section{Cured Pigment and Total Pigment}

There was no an interactive effect between the treatment and storage times on the cured pigment concentration of each treatment at various periods of storage, but the main effect of storage times was significantly $(\mathrm{P}<0.05)$ different (Table 2). The trends indicated that the cured pigment concentration increased significantly $(\mathrm{P}<0.05)$ over time of storage regardless of treatment of fresh celery leaves concentration and incubation temperature. This means that the level of fresh celery leaves in formulation and incubation temperature did not appear to be as important as the amount of time required for enzyme of nitrate reductase of fresh celery leaves or fresh beef to convert nitrate to nitrite. This nitrite was then was converted into nitric oxide (NO) for the development of cured pigment. Parthasarathy and Bryan (2012) reported that a minimum of two hours of incubation is required to convert the $90 \%$ of nitrite to nitric oxide (NO) and bound with myoglobin to form nitrosylmyoglobin. After heating, the globin portion of nitrosylmyoglobin is denatured and escaped from the iron atom to form stable nitrosylmyochrome or nitrosylhemochrome (Pegg and Shahidi, 2008). This process of cured pigment is expected to develops or stabilize throughout the storage periods.

The trends of time observations showed that incubation temperature of $40.6^{\circ} \mathrm{C}$ in natural curing with $22 \mathrm{~g}$ of fresh celery leaves was capable of producing nitric oxide (NO) for more cured pigment formation resulting from conversion of nitrate of fresh celery leaves to nitrite compared with incubation at room temperature. This did not occur when natural curing with $36 \mathrm{~g}$ of fresh celery leaves and incubation temperature of $40.6^{\circ} \mathrm{C}$ which produced less nitric oxide compared with the incubation at room temperature.

Table 1 shows the mean values of total pigment concentration of treatments over storage times. There was no an interactive effect between treatment and storage times on total pigment concentration of each treatment at various storage times. This means that bottom round from some local beef cattle carcasses those were utilized randomly for dendeng sapi mixture of each treatment did not cause variation in total pigment. The total pigment analysis revealed that total pigment concentration for $\mathrm{A}_{0}$ decreased numerically over storage times. The depleting amounts of nitrite reservoir in $\mathrm{A}_{0}$ over storage times may explain this phenomenon. The total pigment of $A_{2}$ and $A_{4}$ tended to increase over storage times. 


\section{Residual Nitrite}

The concentrations of residual nitrites at preand post-incubation of all treatments were under $0.1 \mathrm{ppm}$ or undetectable nearly. It is suggested that available nitrite had been exhausted in the quick curing reactions during chopping and mixing the dendeng sapi mixtures. There was no significant differences for residual nitrites at preor post-incubate in any treatments. The $\mathrm{A}_{0}$ or the control had higher level of residual nitrite at preincubation numerically compared with all other treatments (Table 4). The residual nitrite at postincubation of all treatments tended to be higher than pre-incubation period. This showed the importance of incubation time required for the conversion of nitrate to nitrite. Sindelar et al. (2007a) stated that an increase in incubation time, may increase the level of nitrite.

All treatments contained the residual nitrite under $0.1 \mathrm{ppm}$ or undetectable nearly during at pre- and post-incubation periods for dendeng sapi mixtures. This suggested that available nitrite was used in the regeneration of the rapid curing reactions during the storage times. There was no interactive effect between treatment and storage times interaction on residual nitrite of all treatments (Table 1). The residual nitrite of all treatments numerically increased at day 14 of storage and then decreased at day 28 of storage. A decrease in the residual nitrite at day 28 of storage was as expected, and the levels of residual nitrite diminished over time for all treatments. This observation results agreed with the result of Sindelar et al. (2007a), a decreasing residual nitrite level is accompained with increasing storage times. Sindelar et al. (2007b), also reported that nitrite concentration was affected by storage times and storage temperature. Another explanation was provided by Sindelar et al. (2010), the packaging effects sample of natural cured beef whole muscle jerky stored in vacuum packages. The vacuum-packaged whole muscle jerky had lower residual nitrite than samples stored in aerobic condition. This phenomenon was caused by the product environment being in the reduced state, and then allowing the conversion of nitrite to nitric oxide, thus resulted in the lower residual nitrite levels (Sindelar et al., 2010).

Each pair of the treatment combinations $\left(\mathrm{A}_{1}\right.$ and $\mathrm{A}_{3} ; \mathrm{A}_{2}$ and $\mathrm{A}_{4}$ ) with FCL levels those were held constantly, the residual nitrite levels were unchanged when the incubation temperatures were increased or were differed between room temperature and temperature of $40.6^{\circ} \mathrm{C}$ (Table 1).
Table 4. The Means for Residual Nitrite at Preincubate and Post-incubate

\begin{tabular}{ccc}
\hline \multirow{2}{*}{ Treatment } & \multicolumn{2}{c}{ Residual Nitrite } \\
\cline { 2 - 3 } & Pre-incubate & Post-incubate \\
\hline $\mathrm{A}_{0}$ & 0.075 & Not measured \\
$\mathrm{A}_{1}$ & 0.053 & 0.046 \\
$\mathrm{~A}_{2}$ & 0.048 & 0.061 \\
$\mathrm{~A}_{3}$ & 0.062 & 0.073 \\
$\mathrm{~A}_{4}$ & 0.042 & 0.043 \\
SEM Error & 0.006 & 0.010 \\
\hline
\end{tabular}

SEM : standard error of the means

This pattern occurred at all days over the 28-d storage times. This showed that the amounts celery leaves of $22 \mathrm{~g}$ or $36 \mathrm{~g}$ produced the same levels of residual nitrite converted from nitrates during the 120 minutes of incubation at room temperature or at temperature of $40.6^{\circ} \mathrm{C}$. The available nitrite that has been reacted through curing reactions may result in the low amount of nitrite of all treatments and over storage times.

The residual nitrite of oven dried dendeng sapi of all treatments at days 0,14 and 28 storage still showed safe limits for human consumption related methaemoglobinemia and or the formation of carcinogenic nitrosamines in the human body. BPOM RI set the daily consumption which does not pose a danger to health (Acceptable daily intake, ADI) for potassium or sodium nitrite by 0 to $0.06 \mathrm{ppm}$ or $\mathrm{mg} / \mathrm{kg}$ body weight (BPOM, 2013).

\section{CONCLUSION}

A little amount of fresh celery leaf $(22 \mathrm{~g} / \mathrm{kg}$ of beef) with the incubation for 2 hours at room temperature may be an effective method for creating natural cured dendeng sapi comparable to conventional cured dendeng sapi with the addition of $50 \mathrm{ppm}$ sodium nitrite.

\section{ACKNOWLEDGMENTS}

This research was funded by Tugas Belajar Programme from Agency for Extension and Human Resource Development of Agriculture, 
Ministry of Agriculture, Republic of Indonesia, 2015.

\section{REFERENCES}

Association of Official Analytical Chemists (A.O.A.C.). 1990. Nitrites in cured meat. In: Official Methods of Analysis. 15 ${ }^{\text {th }}$ Ed., Virginia, P. 973.31

Badan Pengawas Obat dan Makanan (BPOM) Republik Indonesia. 2013. Peraturan Kepala BPOM RI Nomor 36 Tahun 2013 tentang Batas Maksimum Penggunaan Bahan Tambahan Pangan Pengawet, Jakarta.

Honikel, K. O. 2008. The use and control of nitrate and nitrite for the processing of meat products. Meat Sci. 78: 68-76.

Hornsey, H.C.. 1956. The colour of cooked cured pork. I. Estimation of the nitric oxide-haem pigment. J. Sci. Food Agric. 7:534-540.

Keeton, J.T., W.N. Osburn, M.D. Hardin, N.S. Bryan and M.T. Longnecker. 2012. A national survey of the nitrite/nitrate concentrations in cured meat products and nonmeat foods available at retail. J. Agric. Food Chem. 60: 3981-3990

Parthasarathy, D.K and N.S. Bryan. 2012. Review: Sodium nitrite: The "cure" for nitric oxide insufficiency. Meat Sci. 92: 274-279

Pegg, R.B. and F. Shahidi. 2008. Nitrite Curing of Meat: The $\mathrm{N}$-nitrosamine Problem and Nitrite Alternatives. John Wiley \& Sons, New Jersey.

Pinotti, A., N. Graiver, A. Califano and N. Zaritzky. 2001. Diffusion of nitrite and nitrate salts in pork tissue in the presence of natrium chloride. J. Food Sci. 67:2165-2171

Sebranek, J. G. and J.N. Bacus. 2007. Natural and organic cured meat products: Regulatory, manufacturing, marketing, quality and safety issues (American Meat Science
Association White Paper Series No. 1). Retrieved August 11, 2015 from American Meat Science Association, web site: http: //www.meatscience.org/Pubs/White \%20Papers/wp_001_2007_Natural_Organic Cured_Meat.pdf

Sindelar, J. J., J.C. Cordray, J.G. Sebranek, J.A. Love and D.U. Ahn. 2007a. Effects of vegetable juice powder concentration and storage time on some chemical and sensory quality attributes of uncured, emulsified cooked sausages. J. Food Sci. 72:S324S332.

Sindelar, J. J., J.C. Cordray, J.G. Sebranek, J.A. Love and D.U. Ahn. 2007b. Effects of varying levels of vegetable juice powder and incubation time on color, residual nitrate and nitrite, pigment, $\mathrm{pH}$, and trained sensory attributes of ready-to-eat uncured ham. J. Food Sci. 72: S388-S395

Sindelar, J. J., M.J. Terns, E. Meyn and J.A. Boles. 2010. Development of a method to manufacture uncured, no-nitrate/nitriteadded whole muscle jerky. Meat Sci. 86: 298-303

Suryati, T., M. Astawan, H. N. Lioe, T. Wresdiyati and S. Usmiati. 2014. Nitrite residue and malonaldehyde reduction in dendengIndonesian dried meat-influenced by spices, curing methods and precooking preparation. Meat Sci. 96:1403-1408

Terns, M. J., A.L. Milkowski, J.R. Claus and J.J. Sindelar. 2011a. Investigating the effect of incubation time and starter culture addition level on quality attributes of indirectly cured, emulsified cooked sausages. Meat Sci. 88:454-461

Terns, M. J., A.L. Milkowski, S.A. Rankin and J.J. Sindelar. 2011b. Determining the impact of varying levels of cherry powder and starter culture on quality and sensory attributes of indirectly cured, emulsified cooked sausages. Meat Sci. 88:311-318 